\title{
FINANCIAL FEASIBILITY OF COMMUNAL HOMESTAY BUSINESS IN ECO-RURAL TOURISM
}

\author{
Mita Erdiaty Takaendengan*1, Ricky Avenzora ${ }^{* * *}$, Dudung Darusman ${ }^{* * *}$, Cecep Kusmana ${ }^{* * * *}$ \\ "Natural Resources and Environmental Management Study Program - IPB University \\ Jl. Lingkar Akademik, IPB Campus, Dramaga, Bogor 16680, Indonesia \\ ${ }^{* *}$ Department of Forest Resources Conservation and Ecotourism, Faculty of Forestry - IPB University \\ Jl. Lingkar Akademik, IPB Campus, Dramaga, Bogor 16680, Indonesia \\ ${ }^{* * *}$ Department of Forest Management, Faculty of Forestry - IPB University \\ Jl. Lingkar Akademik, IPB Campus, Dramaga, Bogor 16680, Indonesia \\ ${ }^{* * * *}$ Department of Silviculture, Faculty of Forestry - IPB University \\ Jl. Lingkar Akademik, IPB Campus, Dramaga, Bogor 16680, Indonesia
}

\begin{abstract}
Homestay is a type of accommodation suitable to increase demand for rural tourism. A communal homestay is a form of cooperation of homestay that provides better opportunities for local hosts to benefit from the business. This study aimed to analyze the economic potential of the communal homestay business in terms of financial feasibility and multiplier effect analysis. Primary data were obtained using observation techniques, semi-structured interviews and questionnaires. Data were analyzed descriptively, qualitatively and quantitatively. The feasibility of study for the communal homestay business used a feasibility analysis (NPV, BCR and IRR), whereas the economic impact of the homestay business used a multiplier effect analysis. The results of the financial analysis of the communal homestay business in the three study location provinces showed results that were feasible to run. Based on the financial feasibility criteria for the communal homestay business, the IC model had the highest values for NPV, BCR dan IRR (NPV = IDR 1. 140.202.993,00; $\mathrm{BCR}=1,28$ and $\mathrm{IRR}=61,15 \%$ ). The multiplier effect of the communal homestay business has had a positive impact which is 1.8 , on increasing regional economic output in the form of an increase in GRDP and absorption of local workers.
\end{abstract}

Keywords: tourism village, financial feasibility, multiplier effect, communal, homestay

\begin{abstract}
Abstrak: Homestay merupakan salah satu jenis akomodasi yang sesuai untuk memenuhi permintaan wisatawan pada wisata pedesaan. Communal homestay adalah bentuk usaha homestay yang dijalankan secara bersama sama yang mampu memberikan peluang lebih baik bagi tuan rumah untuk mendapatkan keuntungan dari usaha yang dijalankan. Penelitian ini bertujuan untuk menganalisis potensi ekonomi dari usaha communal homestay, ditinjau dari kelayakan finansial dan analisis multiplier effect. Data primer diperoleh dengan menggunakan teknik observasi, wawancara semi terstruktur dan kuesioner. Data dianalisis secara deskriptif kualitatif dan kuantitatif. Studi kelayakan usaha homestay komunal menggunakan analisis kelayakan (NPV, BCR dan IRR) dan dampak ekonomi dari usaha homestay menggunakan analisis multiplier effect. Hasil analisis finansial usaha communal homestay di tiga provinsi lokasi penelitian menunjukkan hasil yang layak untuk dijalankan. Berdasarkan kriteria kelayakan finansial usaha homestay komunal, model IC memiliki nilai NPV, BCR dan IRR tertinggi (NPV= $R p$. 1.140.202.993,00; $B C R=1,28$ dan IRR $=61,15 \%$ ). Multiplier effect dari usaha homestay komunal telah memberikan dampak positifyaitu 1,8 terhadap peningkatan output ekonomi daerah berupa peningkatan PDRB dan penyerapan tenaga kerja lokal.
\end{abstract}

Kata kunci: desa wisata, kelayakan finansial, multiplier effect, communal, homestay

\footnotetext{
${ }^{1}$ Corresponding author:

Email: takaendenganmita@gmail.com
} 


\section{INTRODUCTION}

The rapid development of tourism has created upand-coming tourism businesses. Mahdayani (2009) describes five (5) basic principles of ecotourism development in Indonesia, namely conservation, education, tourism, economy and local community participation. The economy in question is an economic activity carried out by local communities to provide income and profits to be sustainable. The involvement of local communities is essential so that an ecotourism development approach is a participatory approach. The development of ecotourism with a participatory approach will impact the community's welfare, and the quality of the environment can be maintained (Asmin, 2017).

Unlike the urban economy, the rural economy is more uniform and traditional. The economy in rural areas also follows regional characteristics. If the village area is close to the coast, most villagers make a living as fishermen or vice versa. If the rural area is in the form of mountains or plains, most of the population makes a living as farmers. In eco-rural tourism, a form of community economy is created, namely, a homestay or accommodation business that uses a private residence as a place for tourists to stay (UNESCO, 2009). Bhuiyan et al. (2013) explain the definition of homestay as a form of accommodation that allows tourists to interact with local communities, cultural heritage and social interactions. The merging of business and rural tourism aspects makes rural tourism business activities very important because it is a standard for measuring investment sustainability through the involvement of local communities. The role of business here is to encourage people to be more creative, innovative and productive (Permana et al. 2014).

In general, homestays are managed independently per individual or private business. The advantage of running a private business is more flexible than the other. However, it also has weaknesses in the form of limited capital resources and the ability to compete. In order to increase resource efficiency and create a healthy business climate, the concept of Communal Homestay is introduced, which means an accommodation business that is managed jointly with the principles of justice and equity. The word communal is often associated with society. According to Echols and Sadly (2002), communal means relate to the general. Communal in this scientific paper is one of the concepts of community empowerment according to ecotourism. Baiquni (in Nawawi, 2013) states that tourism can encourage life change and revive. This change leads to the community, which is expected to provide participation from both the upper and lower classes. Participation of all communities in forming communal homestays is one way to alleviate poverty in rural areas. Communal homestays at the local level have a target so that people who previously did not have the opportunity to own, manage and even feel the benefits of the homestay business will get this opportunity to realize the improvement of people's welfare.

This study intends to analyze the business potential of communal homestay in eco-rural tourism through financial feasibility and the multiplier effect of the economy in the form of increasing GRDP and absorption of local workers. The study locations are Yogyakarta Special Region, West Java and North Sulawesi Province. Financial feasibility analysis is carried out because communal homestay businesses require financial capital to bring profits in a certain period. Furthermore, the communal homestay business is an accommodation business with multiple economic impacts on a regional and national scale. These multiple impacts arise because the communal homestay business involves many sectors ranging from food, property, and services. The approach to conducting a financial feasibility analysis that is commonly used is the analysis of NPV, BCR, IRR, BEP and PP. The reason for choosing the five financial feasibility indicators is that they are more systematic and applicable.

\section{METHODS}

The research was conducted from May 2019 to February 2020 with locations in six tourist villages in three provinces, namely: Brayut Village and Tanjung Village in the Special Province of Yogyakarta (DIY), Banceuy Village and Bunihayu Village in West Java Province and Bahoi Village and Tiwoho Village in the Province of North Sulawesi. The selection of these three locations is based on the different characteristics and types of objects and attractions in the tourist village. Primary data were obtained using observation techniques, semistructured interviews and questionnaires. Observations and interviews were conducted to observe and find out everything related to the communal homestay business. The research instrument in the form of a questionnaire was designed with a closed pattern (close-ended) with 
the guidance of one score one criteria scoring system (Avenzora, 2008).

The questionnaire consists of seven indicators, and each indicator consists of seven aspects of the assessment. Each statement is given a score of 1 to 7 , which aims to assess each aspect and criteria described in the form of questions (indicators). Respondents consisted of two groups: the homestay owner community and the nonowner community. The sampling technique used is the census method aimed at the category of homestay owner community groups, namely determining the sample using all the population. The total number of respondents in this category is 90 people. The purposive sampling technique is used for the category of community groups that are not homestay owners with 486 respondents. General data about homestay businesses were analyzed descriptively qualitatively, while data on people's perceptions of homestay businesses were quantitatively analyzed. In order to determine the feasibility of a communal homestay business, the method used is in the form of a financial feasibility analysis with business feasibility parameters: 1) NPV (Net Present Value), 2) Benefit-Cost Ratio (B/CR), and 3) IRR (Internal Rate of Returns). Additional information related to financial analysis that is also important to know is the Payback Period and Break Event Point. The financial feasibility analysis formula is described as follows.

\section{NPV (Net Present Value)}

NPV is the difference between "present value benefit" and "present value" of the cost, expressed by the formula :

$$
N P V=\sum_{t=0}^{n} \frac{(B t-C t)}{(1+i)^{t}}
$$

Where: $\mathrm{t}$ (project life); i (interest rate); Bt (benefit in year $\mathrm{t}$ ); $\mathrm{Ct}$ (Cost in year $\mathrm{t}$ ). NPV $>0$ :(positive) means the project can be implemented to provide benefits. $\mathrm{NPV}=0$; (equal) means the project returns exactly the cost. NPV $<0$; (negative) the project is not feasible to implement.

\section{Benefit-Cost Ratio (BC Ratio)}

Benefit-Cost Ratio is a comparison between benefits and costs that have been adjusted to the present value. The equation can express the $\mathrm{B} / \mathrm{C}$ ratio:

$$
\text { BC Ratio }=\frac{\sum_{t=0}^{n} \frac{B t}{(1+i)^{t}}}{\sum_{t=0}^{n} \frac{C t}{(1+i)^{t}}}
$$

Where: If $\mathrm{B} / \mathrm{C}>1$, program/project is feasible to implement. If $\mathrm{B} / \mathrm{C}<1$, program/project is not feasible to implement.

\section{Internal Rate of Return (IRR)}

$$
I R R=i_{1}+\frac{N P V_{1}}{N P V_{1}-N P V_{2}} i_{1}-i_{2}
$$

Where: $i_{1}$ (The discount rate that results in a positive NPV); $i_{2}$ (The discount rate that results in a negative $\mathrm{NPV}$ ); $\mathrm{NPV}_{1}$ (Positive Net Present Value); $\mathrm{NPV}_{2}$ (Negative Net Present Value).

\section{Break-Even Point (BEP)}

$\mathrm{BEP}=\mathrm{Tp}-1+(($ cumulative cost before BEP cumulative benefit before BEP)/benefit when reaching BEP)) x 12 Month

Where: BEP (Break Event Point); Tp-1 (year before BEP).

\section{Payback Period}

PBP $=$ Tp- $1+$ (net benefit cumulative before PBP/ (net benefit cumulatif before PBP + net benefit cumulatif after PBP)) x 12 Month

Where: PBP (Pay Back Period); Tp-1 (year before PBP).

Furthermore, to determine the magnitude of the effect of the communal homestay business owner, the InputOutput Table analysis approach needs to be used. The magnitude of the economic impact of communal homestay businesses is calculated from the value of the multiplier effect of the accommodation sector (lodging, hotels and the like) in the Input-Output table multiplied by the total investment value of the communal homestay business. 


\section{RESULTS}

\section{Public Perception of Homestay Business}

The economic aspect of rural communities is essential to discuss to improve rural communities' welfare. Through tourism, especially eco-rural tourism, the economy of rural communities is no longer monotonous but more varied, and homestays, which are smallscale businesses played by the local community, are promising businesses in eco-rural tourism.

There are differences between the homestay owners and non-owners perceptions of the economy in the three provinces where the research is located. Table 1 explains that DIY Province, which does not have homestay owners, is in the medium category at $60 \%$, and homestay owners are in the high category at 58,5\%. It means that people who are not homestay owners feel normal about the impact of tourism on their livelihoods. However, homestay owners feel that tourism provides an impact on their economy. West Java Province has a high category of $64,5 \%$ non-owners and $96,7 \%$ homestay owners, which means that the community agrees with the good impact that tourism has given the advantages to their economy. Similarly, North Sulawesi province, also included in the high category, namely $55,6 \%$ and $81,3 \%$, means that they agree with the good impact that tourism has supported their economy.
The existence of homestays and the duration of operation in each research village can indicate the development of rural tourism in the provinces of DIY, West Java and North Sulawesi. As described in Table 2, DIY rural tourism has already developed with homestays operating for 10-20 years by $22,6 \%$ and are also supported by a large number of visits, as shown in Figure 1.

West Java Province, which can be classified as a developing rural tourism province, can be seen from Table 2. Homestays that operate for about 5-10 years are $73,5 \%$. While the research location in North Sulawesi is categorized in undeveloped rural tourism, it can be proven by all homestays that have operated for less than five years, and the visitation rate is still low, as shown in Figure 1.

The establishment and development of communal homestay businesses that are expected to improve the welfare of rural communities are considered significant based on the number of visits and the number of homestays in the current village, as shown in Table 3. It is very supportive of adding homestays with the concept of communal homestays aimed at people who have not had the opportunity to own and manage homestays to benefit from tourism activities in their villages.

Table 1. Community economic perception of homestay business

\begin{tabular}{|c|c|c|c|c|c|c|c|c|c|c|}
\hline & \multirow{3}{*}{$\begin{array}{l}\text { Economic } \\
\text { aspect }\end{array}$} & \multicolumn{8}{|c|}{ Provinces } & \multirow{3}{*}{$\begin{array}{l}\text { Average } \\
\text { Score } \%\end{array}$} \\
\hline & & \multicolumn{2}{|c|}{ DIY } & \multicolumn{2}{|c|}{ West Java } & \multicolumn{2}{|c|}{ North Sulawesi } & \multicolumn{2}{|c|}{ TOTAL } & \\
\hline & & $\mathrm{n}$ & $\%$ & $\mathrm{n}$ & $\%$ & $\mathrm{n}$ & $\%$ & $\mathrm{n}$ & $\%$ & \\
\hline \multirow[t]{3}{*}{ Non-owner } & Low & 0 & $0,0 \%$ & 0 & $0,0 \%$ & 0 & $0,0 \%$ & 0 & $0,0 \%$ & $72,60 \%$ \\
\hline & Moderate & 81 & $60,0 \%$ & 55 & $35,5 \%$ & 87 & $44,4 \%$ & 223 & $45,9 \%$ & \\
\hline & High & 54 & $40,0 \%$ & 100 & $64,5 \%$ & 109 & $55,6 \%$ & 263 & $54,1 \%$ & \\
\hline \multirow[t]{3}{*}{ Owner } & Low & 1 & $1,9 \%$ & 0 & $0,0 \%$ & 0 & $0,0 \%$ & 1 & $1,0 \%$ & $75,39 \%$ \\
\hline & Moderate & 21 & $39,6 \%$ & 1 & $3,3 \%$ & 3 & $18,8 \%$ & 25 & $25,3 \%$ & \\
\hline & High & 31 & $58,5 \%$ & 29 & $95,7 \%$ & 13 & $81,3 \%$ & 73 & $73,7 \%$ & \\
\hline
\end{tabular}

Table 2. Length of operation of the homestay

\begin{tabular}{|c|c|c|c|c|c|c|c|}
\hline \multirow{3}{*}{ Length of Operation } & \multicolumn{7}{|c|}{ Provinces } \\
\hline & \multicolumn{3}{|c|}{ DIY } & \multicolumn{2}{|c|}{ West Java } & \multicolumn{2}{|c|}{ North Sulawesi } \\
\hline & & $\mathrm{n}$ & $\%$ & $\mathrm{n}$ & $\%$ & $\mathrm{n}$ & $\%$ \\
\hline$<5$ years & & 0 & $0,0 \%$ & 7 & $23,3 \%$ & 16 & $100 \%$ \\
\hline $5-10$ years & 39 & & $73,5 \%$ & 23 & $73,5 \%$ & 0 & $0,0 \%$ \\
\hline $11-20$ years & 12 & & $22,6 \%$ & 0 & $0,0 \%$ & 0 & $0,0 \%$ \\
\hline$>20$ years & 2 & & $3,7 \%$ & 0 & $0,0 \%$ & 0 & $0,0 \%$ \\
\hline
\end{tabular}


Table 3. Number of families, number of homestay and room rate

\begin{tabular}{llccc}
\hline Province & \multicolumn{1}{c}{ Villages } & $\begin{array}{c}\text { Number of } \\
\text { Families }\end{array}$ & $\begin{array}{c}\text { Number of } \\
\text { Homestay }\end{array}$ & Room rate /night (IDR) \\
\hline \multirow{2}{*}{ DIY } & Brayut & 130 & $20=15 \%$ & 100,000 \\
\multirow{3}{*}{ West Java } & Tanjung & 214 & $33=15 \%$ & 100,000 \\
& Banceuy & 308 & $26=8 \%$ & 100,000 \\
& Bunihayu & 1.898 & $4=0,2 \%$ & $100,000-200,000$ \\
& Bahoi & 172 & $14=8 \%$ & 200,000 \\
& Tiwoho & 277 & $2=0,7 \%$ & 200,000 \\
\hline
\end{tabular}

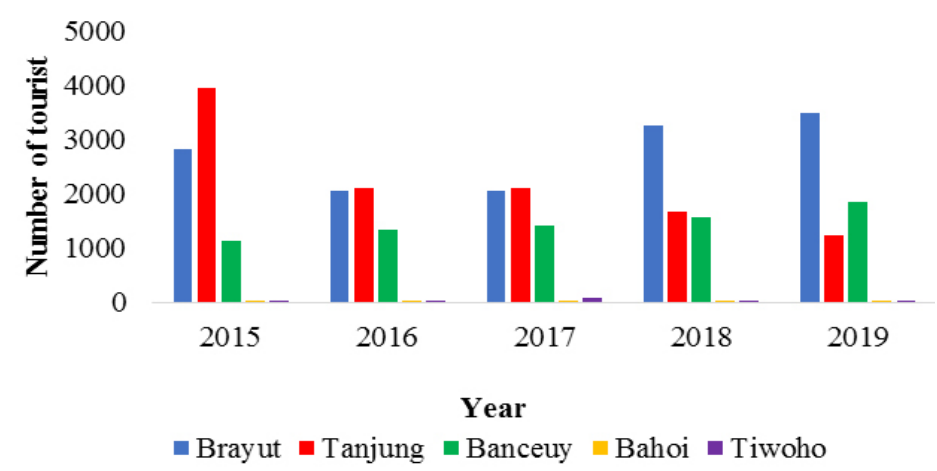

Figure 1. The number of Tourist Visits in Brayut and Tanjung Villages (DIY), Banceuy and Bunihayu Villages (West Java) and Bahoi and Tiwoho Villages (SULUT).

\section{Community Perceptions of the Economic Benefits of Communal Homestay Businesses}

Figure 2 shows that the community's perception score on the economic benefits of the communal homestay business is positive (high enough) with a score of 4,705,45 . According to homestay owners, family income and home asset values are the most dominant benefits. While absorbing labor is in a relatively low score. In general, the homestay owners agree that the communal homestay business brings significant benefits to improving the local economy.

\section{Communal Homestay Business Model}

In this study, the establishment and development of communal homestays were carried out concerning the Regulation of the Minister of Tourism and Creative Economy No. 9 of 2014. The law concerns tourism homestay business standards that spelled out the general provisions that the homestay business provides accommodation in the form of residential buildings inhabited by the owner and partly used for rent with opportunities for tourists to interact in the daily life of the owner. According to the BKKBN, underprivileged communities have low incomes, can survive and do not have a fixed income. There are three (3) models of communal homestays offered in this classification of underprivileged communities, as described in Table 4.

\section{Financial Analysis of Communal Homestay Business}

The financial analysis of the communal homestay business is carried out by calculating the cash inflow and cash outflow during the period of operation. Each business development model is analyzed separately to know the relative level of business feasibility between the models. Some of the assumptions used as the basis for the calculation/financial analysis are as follows:

- The period of exploitation as the basis for calculation is 15 years, taking into account the service life of the homestay building.

- Each homestay unit (1 house) has two rooms, with the rate for each room being IDR200 thousand/ night. The occupancy rate is around $40 \%$.

- The interest rate " $i$ " as the basis for calculating the discount factor to calculate the present value is $12 \%$ obtained from the difference between the real interest rate (loans) and the inflation rate in the last five years. 


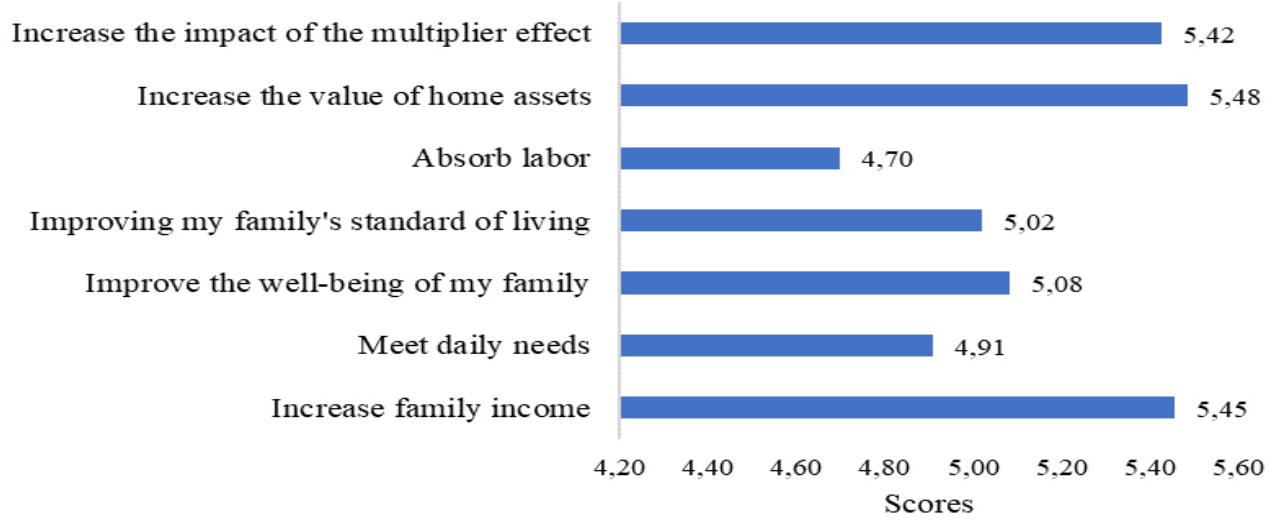

Figure 2. Perceptions of the economic benefits of communal homestay businesses

Table 4. Communal homestay model

\begin{tabular}{|c|c|c|}
\hline $\begin{array}{l}\text { Communal Homestay } \\
\text { Model }\end{array}$ & Criteria & Explanation \\
\hline \multirow[t]{3}{*}{$\begin{array}{l}\text { Underprivileged } \\
\text { communities } 1 \mathrm{~A}\end{array}$} & $\begin{array}{l}\text { The number of members is } 10 \text { people, with } 2 \\
\text { member houses selected as homestays. }\end{array}$ & $\begin{array}{l}\text { The initial investment with KUR loan: IDR. } \\
30 \text { million }\end{array}$ \\
\hline & $\begin{array}{l}\text { Profit-sharing system for member welfare and } \\
\text { business development } 60 / 40\end{array}$ & Profit-sharing with homeowners is $30 \%$. \\
\hline & Short term planning type (1 year or less) & $\begin{array}{l}\text { Investment in room interior facilities: IDR. } 5 \\
\text { million. }\end{array}$ \\
\hline \multirow[t]{3}{*}{$\begin{array}{l}\text { Underprivileged } \\
\text { communities } 1 \mathrm{~B}\end{array}$} & $\begin{array}{l}\text { The number of members is } 15 \text { people, with } 2 \\
\text { member houses selected as homestays. }\end{array}$ & $\begin{array}{l}\text { The initial investment with KUR loan: IDR. } \\
50 \text { million }\end{array}$ \\
\hline & $\begin{array}{l}\text { Profit-sharing system for member welfare and } \\
\text { business development } 70 / 30\end{array}$ & Profit-sharing with homeowners is $30 \%$. \\
\hline & Short term planning type ( 1 year or less)) & $\begin{array}{l}\text { Investment in room interior facilities: IDR. } \\
10 \text { million }\end{array}$ \\
\hline \multirow[t]{3}{*}{$\begin{array}{l}\text { Underprivileged } \\
\text { communities } 1 \mathrm{C}\end{array}$} & $\begin{array}{l}\text { Number of members } 20 \text { people, with } 2 \text { member } \\
\text { houses selected as homestays }\end{array}$ & $\begin{array}{l}\text { The initial investment with KUR loan: IDR. } \\
100 \text { million }\end{array}$ \\
\hline & $\begin{array}{l}\text { Profit-sharing system for member welfare and } \\
\text { business development } 80 / 20\end{array}$ & Profit-sharing with homeowners is $30 \%$. \\
\hline & Short term planning type (1 year or less) & $\begin{array}{l}\text { Investment in room interior facilities: IDR. } \\
20 \text { million }\end{array}$ \\
\hline
\end{tabular}

According to Gray et al. (1985), the financial feasibility of activity is indicated by the NPV (Net Present Value), $\mathrm{B} / \mathrm{C}$ ratio (Benefit-Cost Ratio) or IRR (Internal Rate of Return). The value of NPV, B/C ratio and IRR, are interrelated. An activity is financially feasible (profitable for entrepreneurs) if the NPV value is positive. With a positive NPV value, the $\mathrm{B} / \mathrm{C}$ ratio value will be greater than one, and the IRR value is greater than the discount rate used so that one of the three values can be used to decide whether an activity will be profitable or not financially feasible. All components of costs and income are then poured into a cash flow table with the help of Microsoft Excel software. Expenditures in working capital or variable costs are calculated to increase by $5 \%$ every year. Likewise, the income component is projected to increase by $5 \%$ every year.
The communal homestay business in model $1 \mathrm{~A}$ is the most straightforward homestay business with a community consisting of 10 people and located in 2 selected member houses with four rooms being rented out. The initial investment of IDR50,000,000 with a variable cost of IDR $82,800,000$ per year. Around $70 \%$ of the initial investment came from loans under the Micro People's Business Credit scheme (maximum loan of IDR 50 million), and about $30 \%$ was own capital. The cost required to renovate buildings and furniture every five years is IDR 25,000,000. Revenue from room rental with a $40 \%$ occupancy rate is IDR $116,800,000$. From the cash flow calculation, the communal homestay business model $1 \mathrm{~A}$ has a profit percentage of $17 \%$ and is feasible to operate with the financial feasibility 
parameters, namely: NPV of IDR151,478,609; B/C ratio 1.17; IRR $44.60 \%$, Pay Back Period $=2.5$ years and $\mathrm{BEP}=2.09$ years. Components of expenses/costs and business income of Communal Homestay (IDR/ year) in Table 5.

The communal homestay business in model $1 \mathrm{~B}$ is a moderate category homestay business with a community consisting of 15 people and located in 5 selected member houses with ten rooms being rented out. The initial investment of IDR125,000,000 with a variable cost of IDR195,000,.000 per year. Around $70 \%$ of the initial investment came from loans under the Retail People's Business Credit scheme (maximum loan of IDR500 million), and around 30\% was own capital. The cost required to renovate buildings and furniture every five years is IDR62,500,000. Revenue from room rental with a $40 \%$ occupancy rate is IDR292,000,000. From the cash flow calculation, the communal homestay business model $1 \mathrm{~B}$ has a profit percentage of $22 \%$ and is feasible to operate with the financial feasibility parameters, namely: NPV of IDR
474,413,771; B/C ratio 1.22; IRR 52.83\%, Pay Back Period $=2.08$ years and $\mathrm{BEP}=2.02$ years.

The communal homestay business in model $1 \mathrm{C}$ is a large category homestay business with a community consisting of 20 people and located in 10 selected member homes with 20 rooms being rented out. The initial investment of IDR250,000,000 with a variable cost of IDR366,000,000 per year. Around 70\% of the initial investment came from loans under the Retail People's Business Credit scheme (maximum loan of IDR500 million), and around 30\% was own capital. The cost required to renovate buildings and furniture every five years is IDR125,000,000. Revenue from room rental with a $40 \%$ occupancy rate is IDR584,000,000. From the calculation of cash flow, the communal homestay business model $1 \mathrm{C}$ has a profit percentage of $28 \%$ and is feasible to operate with the financial feasibility parameters, namely: NPV of IDR 1,140,202,993; B/C ratio 1.28; IRR 61.15\%, Pay Back Period $=1.77$ years and $\mathrm{BEP}=1.18$ years.

Table 5, Components of expenses/costs and business income of Communal Homestay (IDR/year)

\begin{tabular}{|c|c|c|c|}
\hline Components of expenses/costs (IDR/year) & $\begin{array}{l}\text { Model IA } \\
\text { ( } 2 \text { houses, } \\
4 \text { rooms) }\end{array}$ & $\begin{array}{c}\text { Model IB } \\
\text { (5 houses, } 10 \\
\text { rooms })\end{array}$ & $\begin{array}{c}\text { Model IC } \\
\text { (10 houses, } \\
20 \text { rooms) }\end{array}$ \\
\hline \multicolumn{4}{|l|}{ Expenses } \\
\hline \multicolumn{4}{|l|}{ Initial Investment } \\
\hline House renovation (IDR, 15 million/house) & $30,000,000$ & $75,000,000$ & $150,000,000$ \\
\hline Furniture (IDR. 5 million/room) & $20,000,000$ & $50,000,000$ & $100,000,000$ \\
\hline Total & $50,000,000$ & $125,000,000$ & $250,000,000$ \\
\hline \multicolumn{4}{|l|}{ Investment in rehabilitation \& Facility renovation } \\
\hline House renovation 5 yaers (IDR. 7,5 million/house) & $15,000,000$ & $37,500,000$ & $75,000,000$ \\
\hline Facilities renovation (IDR. 2,5 million/room) & $10,000,000$ & $25,000,000$ & $50,000,000$ \\
\hline Total & $25,000,000$ & $62,500,000$ & $125,000,000$ \\
\hline Variable cost (IDR/year) & & - & - \\
\hline Water, electricity \&Internet (IDR. $150 \mathrm{rb} / \mathrm{room} / \mathrm{month}$ ) & $7,200,000$ & $18,000,000$ & $36,000,000$ \\
\hline Toiletries (IDR. 75 thousand/room/month) & $3,600,000$ & $9,000,000$ & $18,000,000$ \\
\hline Administration and Marketing & $24,000,000$ & $48,000,000$ & $72,000,000$ \\
\hline Janitor \& security/house x 12 months/room) & $48,000,000$ & $120,000,000$ & $240,000,000$ \\
\hline Total & $82,800,000$ & $195,000,000$ & $366,000,000$ \\
\hline Investment depreciation (/15 years) & $3,333,333$ & $8,333,333$ & $16,666,667$ \\
\hline $\begin{array}{l}\text { loan instalment (IDR/year) Tenor } 4 \text { Years loan } 70 \% \text { from } \\
\text { initial investment. *) }\end{array}$ & $9,864,000$ & $24,648,600$ & $49,296,000$ \\
\hline Local tax (10\% from benefit) & $\begin{array}{l}\text { According to } \\
\text { profit }\end{array}$ & $\begin{array}{l}\text { According to } \\
\text { profit }\end{array}$ & According to profit \\
\hline \multicolumn{4}{|l|}{ Investment in rehabilitation $\&$ Facility renovation } \\
\hline House renovation 5 yaers (IDR. 7,5 million/house) & $116,800,000$ & $292,000,000$ & $584,000,000$ \\
\hline
\end{tabular}

Note $*$ ) $=$ Table of reference for BRI Micro KUR installments $<50$ million and BRI Retail KUR $>50$ million with an interest rate of $6 \%$. 
The results of the financial analysis of the communal homestay business in the three provinces of the research location show results that are feasible to run. From the NPV parameter, all communal homestay business development models (1 A, $1 \mathrm{~B}$ and $1 \mathrm{C}$ ) have a positive value with a profitability level of approximately $17 \%$ to $28 \%$. The Benefit-Cost Ratio parameter of the three models also shows a value is more than one, and the IRR value is greater than the loan interest rate. Pay Back Period and BEP under three years from the business age of 15 years. Based on the analysis of the financial feasibility of communal homestay businesses in tourist villages, there are vast opportunities for local communities to optimize various tourism service businesses, especially the business of providing lodging accommodation. With financial capital that is still affordable for small and medium-sized businesses, various tourism driving groups such as Pokdarwis, micro-enterprise cooperatives and regionally-owned enterprises can participate in the communal homestay business.

As a comparison, several financial feasibility studies of the tourist accommodation business in lodging have shown financially feasible results. Arini et al. (2012) mentioned that the Guest House business in Bandar Lampung City, Lampung Province is financially feasible. The investment feasibility parameters obtained are NPV value of IDR831,444,542,44 (positive); B/C Ratio $=1.633 ;$ IRR $=20.62 \%$; Pay Back Period for eight years two months 23 days, and Break Event Point for eight years 25 days. The assumptions used are that the number of rooms is six units, the occupancy rate is $35 \%$, the interest rate is $\mathrm{i}=14 \%$ and the business life is 20 years. In addition, Ramdhani et al. (2016) stated that the Novotel Hotel in Pekanbaru Riau (a 4-star hotel) also provides financially feasible results. The parameters of the investment feasibility value obtained are NPV value of IDR21,372,648,415 (positive); B/C Ratio $=1.05455 ;$ IRR $=16.61 \%$; Pay Back Period for eight years 7 months assuming the number of rooms is 4 with 197 rooms, occupancy $46.49 \% ; i=15.01 \%$ and operating life of 10 years. Furthermore, the financial analysis of the type of villa accommodation in Ubud Bali conducted by Sindudarmo and Sedana (2018) is also reported to be financially feasible. The parameter NPV $=\operatorname{IDR} 7,244,872,000 ; \mathrm{B} / \mathrm{C}$ Ratio $=1.15$, with an IRR of $13.55 \%$; The payback period is 5.97 years assuming an interest rate of $i=10.77 \%$ and a period of 10 years.
Another research conducted by Sulton et al. (2018) calculated the financial analysis of accommodation type Komdominium hotel (Condotel) conducted the Pekanbaru Park Condotel in Riau Province. The result also reported to be financially feasible as seen from the positive NPV value (IDR67,877,696,368.23); $\mathrm{BCR}=$ $1.2 ; \quad \operatorname{IRR}=24,97 \%$, Pay Back Period $=9$ years 17 months 17 days assuming an interest rate of $13.5 \%$, occupancy $66 \%$ and a period of 50 years.

The communal homestay business has a competitive advantage compared to other types of accommodation. Financially, the communal homestay business is not considered a capital-intensive business but tends to be labor-intensive and efficient in resource use. Even though it is simple in physical form, comfort and cleanliness remain the main priority and follow the standards of the lodging accommodation business issued by the authorized institution. The tourists' activities in the homestays are varied. Not only staying but also experience to live together with the local community and all the norms and rules.

\section{Economic Impact of Communal Homestay}

Tourism has a very close economic relationship with various other development sectors. The money that tourists have spent in a region or country and various investment activities in the tourism sector will affect the income level of the local community and the level of employment absorption. Various works of literature mentioned that the tourism sector could provide economic impacts in many forms. For example, they are increasing people's income, increasing state and regional income, increasing taxes and foreign exchange, increasing job opportunities and business opportunities, and various financial benefits from tourism businesses run by tourism object managers. The tourism sector is expected to absorb the local workforce and provide a high multiplier effect on the flow of economic transactions in a region or country (Yoeti, 2008). The Communal Homestay business includes a tourism service business with a multiplier effect value of more than 1. Table 6 stated that the multiplier rate for the tourist accommodation sector (lodging, hotels and others) is around $1.8-2$ multiplied by the total value of the homestay business, the total output value of the homestay accommodation business will be obtained for one year. 
The basis for calculating the economic impact of the communal homestay business is the value of the homestay business per room multiplied by the multiplier effect of the accommodation business of 1.8. The homestay business value is the sum of the rental value per room and the investment value (starting capital and working capital) homestay per room per year. Table 7 shows that the economic impact of the homestay business nationally is around IDR13.511 trillion, with a projected room occupancy rate of around $40 \%$. Furthermore, the employment impact for homestay businesses is 67,405 people (number of businesses $\mathrm{x}$ number of workers $=13,481 \times 5$ people $=67,405$ ). The multiplier effect for the homestay accommodation business was 1.8 , which is categorized as relatively high. This figure was obtained from the Indonesian Input - Output Table analysis for 2010 and the 2016 National Tourism Satellite Account. The multiplier of 1.8 means that the communal homestay business could impact regional economic output by 1.8 times the real (direct) transaction value.

The Communal Homestay business needs to be carried out collaboratively between tourism industry business actors (investors), the government, and the surrounding community so that there is no vertical conflict in the form of unfair business competition. The tourism industry business actors have significant financial capital and greater capacity to manage the lodging accommodation business. Meanwhile, local community groups have assets in the form of social capital and potential sources of labor to support the rural tourism industry. The cooperation between the people who own capital and the surrounding community (lower communities) must be established and facilitated by government agencies. The form of collaboration can be formulated based on an agreement between the two parties. Several collaboration concepts that can be proposed include 1) Equity participation by tourism business actors, 2) Business assistance, 3) Integration of tourism products, and 4) Joint promotion.

Capital participation from tourism business actors in the communal homestay business can be in the form of initial investment capital or working capital. The reward system is a profit-sharing pattern agreed upon by both parties. With this capital participation, the community group of Communal Homestay business actors will not be burdened with bank loan installments due to debt for initial investment. Communal homestay entrepreneurs will also feel confident because experienced investors in the accommodation business support them.

Table 6. Non-hotel accommodation services

\begin{tabular}{lccc}
\hline Provinces & Number of business & Number of room & Number of bed \\
\hline DI Yogyakarta & 1,043 & 7,977 & 14,829 \\
West Java & 1,516 & 14,009 & 19,944 \\
North Sulawesi & 111 & 1,225 & 1,563 \\
National & 13,481 & 125,104 & 170,422 \\
\hline
\end{tabular}

Source: Hotel Statistics and other Accommodation Services (BPS, 2019).

Table 7. Potential homestay investment

\begin{tabular}{lcrr}
\hline \multicolumn{1}{c}{ Province } & $\begin{array}{c}\text { Number of room Homestay } \\
\text { (unit) }\end{array}$ & $\begin{array}{c}\text { Estimated Value of } \\
\text { Homestay Business (IDR) }\end{array}$ & Economic impact (IDR) \\
\hline DI Yoyakarta & 7,977 & $478,620,000,000$ & $861,516,000,000$ \\
West Java & 14,009 & $840,540,000,000$ & $1,512,972,000,000$ \\
North Sulawesi & 1,225 & $73,500,000,000$ & $132,300,000,000$ \\
National & 125,104 & $7,506,240,000,000$ & $13,511,232,000,000$ \\
\hline
\end{tabular}

Note: Business value $=$ investment value + tourist stay rental spending $=$ IDR 60 million/room.

The value of the multiplier effect of the accommodation business used is 1,8 . 
Based on the financial feasibility study results and the regional economic impact (multiplier effect), the communal homestay business was very prospective to be developed as a rural accommodation business unit. It was very strategic as an effort to encourage regional economic growth. Local governments must encourage and facilitate communal homestay business actors in terms of capital facilitation and regulations. Community groups involved in the tourism village business must be more enthusiastic and always follow the development trend of the tourism village business. Furthermore, large-scale and modern accommodation business actors such as hotels and the like must provide assistance and training to rural communities who run homestay businesses to create cooperation and suitable accommodation business cooperation.

\section{Managerial Implications}

Tourism in this case the establishment and development of communal homestays in rural tourism can increase the economic growth of rural communities. With the existence of communal homestays, can be confirmed that product diversification will be wider which will be able to increase the income of rural communities. By optimizing local products can maintain the multiplier remains high.

\section{CONCLUSIONS AND RECOMMENDATIONS}

\section{Conclusions}

The results of the financial feasibility analysis show that the concept of communal homestay proposed in models 1A, 1B and 1C are all feasible. Communal homestay businesses can be an alternative for developing various tourism service businesses, especially in rural tourism. Financial capital for the development of communal homestay businesses can come from the bank loan capital (Kredit Usaha Rakyat) or other more competitive and lighter sources in installments. Tourism businesses, especially communal homestay businesses in tourist villages, also significantly impact the regional economy as a multi-sectoral field. The multiplier effect of the communal homestay business has had a positive impact on increasing regional economic output in the form of an increase in GRDP and absorption of local workers.

\section{Recommendations}

To continue this research need to conduct sensitivity analysis with several alternative interest rates as well as source of capital loan. It will enrich the result of this research and also the benefit for local people.

\section{REFERENCES}

Arini YW, Wulan S, Putra AR. 2012. Analysis of the feasibility study of the Guest House Family business in Bandar Lampung. Journal of Management and Business 3(1): 77-100.

Asmin F. 2017. Ecotourism and Sustainable Development (Starting from Simple Concepts). Padang.

Avenzora. 2008. "Assessment of Tourism Object Potential: Assessment Aspects and Indicators" in Avenzora (Ed) Ecotourism: Theory and Practice. Banda Aceh (275-314). BRR NAD - Nias.

Bhuiyan S, Islmail. 2013. Socio-economic Impacts of Homestay Accomodation I Malaysia: A study on Homestay operators in Terengganu State. Asian Social Science Journal 9 (3):42-49. https://doi. org/10.5539/ass.v9n3p42

Echols JM, Sadily H. 2003. English Indonesia Dictionary. Jakarta: PT. Gramedia.

Gray C, Karlina L, Kadariah. 1985. Introduction to Project Evaluation. Jakarta:First Edition PT.Gramedia.

Mahdayani W. 2009. Buku Panduan Dasar Pelaksanaan Ekowisata. Nias: Dinas Pariwisatadan Kebudayaan Kabupaten Nias Selatan

Nawawi A. 2013. Partisipasi masyarakat dalam pengelolaan wisata pantai depok di desa kretek parangtritis. Jurnal Nasional Pariwisata 5(2): 103-109.

Permana BU, Wisadirana D, Mardiyono. 2014. Community strategy through creative economic innovation in poverty alleviation (Case Study of Non-Machine Weaving Craft Industry in Purwosari District, Pasuruan Regency). Wacana Journal 17 (4):246-254.

Ramdhani F, Irwandi D, Darfia NE, Basri DR. 2016. Feasibility analysis on Novotel hotel investment in Pekanbaru City. Jurnal Rab Construction Research 1(2):106-119.

Sindudarmo TS, Sedana IBP. 2018. Feasibility study the Gangga Ubud Private Villa \& Spa di Desa Payogan, Kecamatan Ubud, Kabupaten Gianyar 
Bali. Jurnal Ekonomi dan Bisnis Universitas Udayana 7(9): 2191-2216. https://doi. org/10.24843/EEB.2018.v07.i09.p05

Sulton ES, Taufik H, Sebayang M. 2018. Overview of the financial feasibility of a Condotel-type hotel: Case Study of the Pekanbaru Condotel Development Project Park. Jom FTEKNIK 5(1):1-10.
UNESCO. 2009. Ecotourism: A Basic Guide to Implementation. Jakarta: United Nations Educational, Scientific and Culturan Organization.

Yoeti OA. 2008. Tourism Economics Introduction, Information and Applications. Jakarta: KOMPAS. 